\title{
The Funny Thing Is, Instructor Humor Style Affects Likelihood of Student Engagement
}

\author{
Kristie Nienaber \\ Nienaber Counseling \\ Gwyneth Abrams \\ Canadian Coast Guard \\ Dan Segrist \\ Southern Illinois University Edwardsville \\ dsegris@siue.edu
}

\begin{abstract}
Instructors often use bumor in teaching their classes. Research suggests that bumor can affect how instructors and their teaching are perceived. The current study examined whether the type of humor used by a hypothetical instructor and instructor gender affected the perceived likelihood of engaging with the instructor. College students read a vignette describing the teaching and bumor used by a bypothetical instructor. The likelihood that students would engage with the instructor was highest when the instructor's humor style was good-natured and lowest when it was hostile and sarcastic. Instructor gender had no effect on students' likelihood of engaging with the instructor.
\end{abstract}

Keywords: humor, student engagement

Instructors are often encouraged to incorporate humor into their teaching and frequently do so (Martin, 2007; Torok, McMorris, \& Linn, 2004). Multiple authors have reviewed the literature on the use and effect of humor in the college classroom (see Banas, Dunbar, Rodriguez, \& Liu, 2011; Martin, 2007; Martin, Preiss, Gayle, \& Allen, 2006; Oppliger, 2003; Powers, 2008; Segrist \& Hupp, 2015). Proponents of the use of humor suggest that humor can have positive effects on students, the retention of material, and the learning environment (e.g., Berk, 2002; Deitar, 2000; Garner, 2006). Torok, McMorris, and Lin (2004) point out that, "Humor, appropriately used, has the potential to humanize, illustrate, defuse, encourage, reduce anxiety, and keep people thinking” (p. 14).

Professors who incorporate humor in their teaching may be more positively evaluated by students (e.g., Bryant, Comisky, Crane, \& Zillmann, 1980; Garner, 2006; Van Giffen, 1990; Wanzer \& Frymier, 1999). Increased use of humor has also been associated with increased instructor immediacy (Gorham \& Christophel, 1990; Wanzer \& Frymier, 1999). Wilson and Taylor (2001) found that instructor humor positively related to students' perceptions that instructor "wanted them to succeed" and had a "genuine concern" for and "positive attitude toward" them (pp. 136-137). Instructor humor can even affect students' willingness to engage an instructor outside of class. Aylor and Oppliger (2003) found that instructors' use of humor in the classroom predicted the frequency of students' outof-class communication with those instructors. More recently, Goodboy and colleagues (2015) demonstrated that college students' ratings of the frequency and effectiveness of an instructor's humor predicted both in-class participation and out-of-class communication with that instructor.

Hackathorn and colleagues (2011) found that when instructors used humor to teach material, students demonstrated better knowledge and comprehension of the material than when instructors did not use humor. Although research evidence demonstrates that humor can augment teaching efforts, it is not a magic bullet. In fact, the effects of instructor humor are not always positive or appreciated. For example, in general students consider it inappropriate for teachers to use hostile 
humor, disparaging humor, sexual humor, or humor that targets students individually or collectively (e.g., humor targeting sex, sexual orientation, ethnicity, or religion; Torok, McMorris, \& Lin, 2004; Wanzer, Frymier, Wojtaszczyk, \& Smith, 2006). Furthermore, hostile humor can create an adverse classroom milieu (Stuart \& Rosenfeld, 1994).

Research on the use of humor in teaching has suggested that students' perceptions of instructor humor, as well as the effect of that humor, may be influenced by the gender of the instructor. For example, Van Giffen (1990) found that for female instructors, but not male instructors, the use of humor was predictive of perceived instructor effectiveness. Gorham and Christophel (1990), however, found that although male and female instructors in their study used similar forms of humor, only use of humor by male instructors related to students' self-reported learning. Bryant, Commiskey, Crane, and Zillman (1980) found that the use of humor was positively related to the perceived effectiveness and appeal of male instructors. For female instructors, no forms of humor were positively related to perceived effectiveness but some (i.e., puns, distracted humor) were negatively associated with perceived effectiveness and appeal. Hostile humor was positively related to the perceived effectiveness of male instructors while aggressive and sexual/hostile humor were associated with increased appeal for female instructors. In her review of the literature on humor and learning, Oppliger (2003) called for more research examining humor in instructor gender and the use of humor in teaching.

The present study examined the effect of the type of humor used by a hypothetical professor on students' perceived likelihood of engaging with that professor. Because previous research suggests that the perception of instructor humor may be affected by instructor gender as well as the interaction of instructor gender and humor type, the present study included both humor type and instructor gender as variables. We also speculated that introversion might affect students' comfort with interacting with a professor in or out of class, (regardless of that professor's use of humor). As a result, we included introversion as a control variable.

\section{Method}

\section{Participants}

The sample included 157 undergraduate students attending a Midwestern public university and was comprised primarily of freshmen $(53.5 \%)$ and sophomores $(27.4 \%)$ with a mean age of 19.79 years $(S D=2.58)$. The majority of participants identified as female $(75.2 \%)$ and ethnically as Caucasian $(61.1 \%)$ or African American (32.5\%).

\section{Materials and Procedure}

Participants who signed up for this study were provided with a Survey Monkey link through which they could access the study. After providing consent, participants completed demographic questions. In order to randomly assign vignette condition, participants also indicated their birth month. Based on birth month, the survey directed participants to one of six possible vignettes briefly describing a hypothetical college professor and his or her teaching style and use of humor in the classroom. Subsequently participants rated a series of items about the likelihood of engaging and comfort level with the instructor. Participants also completed an introversion measure. 


\section{Vignettes}

The vignettes (Appendix 1) briefly described "Professor Morgan" who is teaching Psychology 101. The vignette included information about Professor Morgan's teaching style and use of humor in teaching. Six vignettes were created and varied by professor gender and the professor's use of humor in teaching (i.e., affiliative humor, aggressive humor, little/no humor). For the vignettes that depicted Professor Morgan using humor in teaching, descriptions of the professor's style of humor were drawn from items comprising two of the four subscales included in the Humor Styles Questionnaire (Martin et al., 2003). Affiliative humor is, "an essentially non-hostile, tolerant form of humor that is affirming of others and presumably enhances interpersonal attraction and cohesion" (Martin et al., 2003, p. 53). Aggressive humor includes sarcasm and using humor to "ridicule and manipulate others" (Martin, 2003, p. 23). As can be seen in Appendix A, the "little/no" humor vignette is shorter than the "affiliative" and "aggressive" humor vignettes. Although all three vignettes would ideally be the same length, we felt it was important to keep the content of the vignettes focused on the humor style.

\section{Engaging with Professor Scale}

Participants' likelihood of engaging and comfort level with the hypothetical professor was assessed through nine items based loosely on original item pool for the Professor-Student Rapport Scale (Wilson, Ryan, \& Pugh, 2010) and tailored to the vignette character (i.e., Professor Morgan; see Table 1). Items encompassed potential student behaviors and attitudes reflecting willingness to engage and comfort level with the instructor and the instructor's class (e.g., I would feel comfortable asking a question during class; I would enjoy having this professor; I would participate in class discussions in Professor Morgan's class) as well as the likelihood of contacting the professor outside of class (e.g., I would go to Professor Morgan's office hours; I would email Professor Morgan with a question or concern about class; I would feel comfortable letting Professor Morgan know I need belp with class material). Items were rated on a five-point Likert scale $(1=$ strongly disagree...5=strongly agree). Total scores could range from 9 to 45 , with higher scores reflecting increased likelihood of engagement. Cronbach's alpha for the scale was .94.

\section{Table 1: Items comprising the Engaging with Professor Scale}
I would go to Professor Morgan's office hours
I would participate in class discussions in Professor Morgan's class
I would be motivated to attend Professor Morgan's class
I would feel comfortable in Professor Morgan's class
I would email Professor Morgan with a question or concern about class
I would feel comfortable letting Professor Morgan know I need help with class material
I would point out a mistake on Professor Morgan's slides/lecture during class
I would feel comfortable asking a question during class
I would enjoy having this professor

\section{Introversion}

Introversion was assessed through a 10-item International Personality Item Pool (Goldberg, et al., 2006) scale based on the California Psychological Inventory (Gough \& Bradley, 1996). In the present study, Cronbach's alpha for the scale was .75.

Journal of the Scholarship of Teaching and Learning, Vol. 19, No. 5, December 2019. josotl.indiana.edu 


\section{Results}

We intended to analyze data using a 2 X 3 between groups ANCOVA in order to control for participant introversion; however, there was not a significant relationship between introversion scores and the perceived comfort level with the professor $(r=.04, p=.604)$. Consequently, introversion was not used as a covariate and a 2 X 3 between groups ANOVA was conducted to assess the effect of professor humor style and professor gender on students' comfort level and likelihood of engaging with the professor. The independent variables were gender of the hypothetical professor and style humor of used - affiliative, aggressive, or little/no humor. The dependent variable was likelihood of engaging with the professor.

The interaction between professor gender and humor style was not significant, $F(2,146)=$ $.65, p=.525$. The main effect for instructor humor style was significant, $F(2,146)=71.37, p<.01, \eta^{2}$ $=.49$. Post-hoc comparisons using the Tukey HSD test indicated significant differences at the $p<.05$ level among all three humor conditions (Figure 1). Students were more likely to engage with a professor portrayed as using affiliative humor $(M=38.10, S D=5.61)$ compared to little/ no humor $(M=26.19, S D=6.27)$ and aggressive humor $(M=21.70, S D=7.70)$. There was not a significant main effect for professor gender, $F(1,146)=.11, p=.738$.

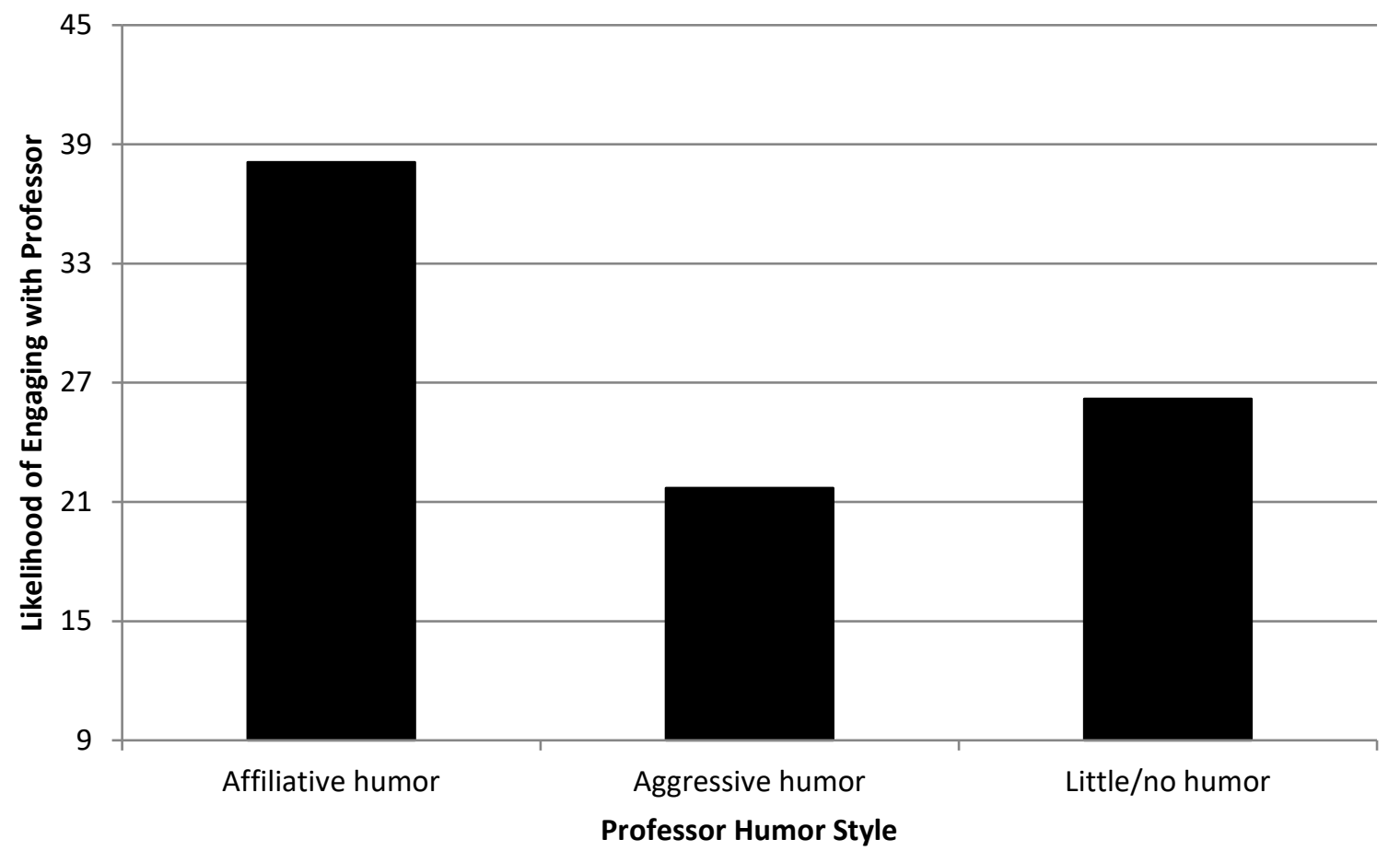

Figure 1: Likelihood of Engaging with Professor based on Type of Humor Used

\section{Discussion}

The results of the present study suggest that students are more likely to engage and feel comfortable with an instructor who uses affiliative humor as opposed to hostile humor or no humor at all. The difference between the likelihood of engagement ratings for affiliative humor and aggressive humor or no humor are striking. In the affiliative humor condition, comfort ratings are well above the scale median (almost two standard deviations above the median). Research has demonstrated a relationship 
between instructor humor and immediacy (e.g., Gorham \& Christophel, 1990; Wanzer \& Frymier, 1999; Wilson \& Taylor, 2001). The present study extends this research by demonstrating that different types of humor have different effects on the likelihood of engaging with a professor. Specifically, students were more likely to engage with a professor whose classroom humor was affiliative. This type of humor is a non-threatening form of humor that fosters social bonding (Martin, 2003). Yip and Martin (2006) found that affiliative humor was positively associated with social competence, more specifically initiating relationships and disclosing personal information. Although further research would be needed to test this assertion, the present results suggest that students may have associated the use of affiliative humor with an increased level of social competence and, consequently, imagined feeling more comfortable with "Professor Morgan".

Findings also indicated that students felt more comfortable engaging a professor who used no humor in the classroom than one who used aggressive humor. In fact, in the aggressive humor condition, ratings of perceived comfort with "Professor Morgan" were well below the median of the scale. Wanzer, Frymier, and Irwin (2010) found that a professor's use of disparaging humor was not related to student learning. However, research also indicates that students perceive instructor humor that demeans students as inappropriate (Frymier, Wanzer, \& Wojtaszczyk, 2008). Although humor that ridicules might not adversely affect learning, the results of the present study suggest that disparaging humor affects students' comfort with a professor and could, consequently, become a barrier preventing students from seeking help from an instructor. Yip and Martin (2006) found that the use of aggressive humor was negatively associated with emotional perception, emotional support, and conflict management. Perhaps students' low likelihood of engaging with an instructor who used aggressive humor reflects students' assumptions that such an instructor would lack empathy or understanding. Students might understandably be less comfortable approaching or interacting with a professor who uses humor to ridicule and does not seem emotionally supportive.

Interestingly, instructor gender did not interact with type of humor to influence students' comfort level with "Professor Morgan". Much of the research on gender and instructor humor is somewhat dated. It may be that perceptions of instructor humor are not affected by an instructor's gender to the degree or in the same way they were 20 to 30 years ago. However, we concur with Oppliger's (2003) suggestion that more research examining the interaction of instructor gender and instructor humor is warranted.

The current study has a few important limitations. In this study participants were asked to rate items asking about their comfort level with a hypothetical professor. The vignettes provide little information beyond professor gender, course, general teaching style, and type of humor used while teaching. This means that participants lacked other contextual cues (e.g., the specific jokes, delivery, situation). Humor, however, is largely a social experience (Martin, 2007) that is context dependent (Lampert \& Ervin-Tripp, 1998 as cited in Crawford, 2003). For example, people tend to laugh more often when they are with others (Martin \& Kuiper, 1999). Because participants read about a professor's style of humor, but did not experience an actual professor using humor in a classroom setting the present results should be interpreted with some caution. Future studies might address this methodological issue by showing groups of participants video clips of a professor using humor while teaching.

The majority of participants in this study were first year college students. As a result, their exposure to college professors was fairly limited. As students matriculate they may experience a greater variety of instructors as well as a greater diversity in how humor is used in the classroom. Consequently, the influence of instructor humor on students may change as the student becomes a more seasoned college student. Future studies could explore whether the effect of instructor humor varies as a function of students' matriculation level.

Journal of the Scholarship of Teaching and Learning, Vol. 19, No. 5, December 2019. josotl.indiana.edu 


\section{Appendix}

\section{Appendix 1. Vignettes.}

\section{No Humor}

Professor Morgan teaches Psychology 101. Colleagues would describe her as being highly knowledgeable in course subject matter. During lectures, Professor Morgan is very serious. For example, she rarely if ever makes a joke during class. In general, Dr. Morgan can be described as serious and thorough.

\section{Aggressive Humor}

Professor Morgan teaches Psychology 101. Colleagues and students would describe her as being highly knowledgeable in the course subject matter. During lectures, Professor Morgan is very thorough and uses a lot of humor to maintain students' attention. For example, if a student makes a mistake in class, Professor Morgan often teases them about it, without showing concern about how others are taking her jokes. If something is really funny she will not hesitate to laugh and joke about it, even if someone might be offended. At times Professor Morgan also uses humor at the expense of others. Professor Morgan teases and puts down students she dislikes. Some students are offended by her sense of humor. In general, Dr. Morgan's humor would be considered sarcastic, insensitive, and at times offensive.

\section{$\underline{\text { Affiliative Humor }}$}

Professor Morgan teaches Psychology 101. Colleagues and students would describe her as being highly knowledgeable in the course subject matter. During lectures, Professor Morgan is very thorough and uses a lot of humor to maintain students' attention. For example, Professor Morgan often jokes around and laughs with other students during class. Most students consider her to be a naturally humorous, witty, and an amusing person. During lectures, Dr. Morgan uses humor that revolves around funny stories in her life. Dr. Morgan finds enjoyment in making students, colleagues, and friends laugh. In general, Dr. Morgan's humor would be considered light-hearted, amusing, charming, and cheerful.

\section{References}

Aylor, B., \& Opplinger, P. (2003). Out-of-class communication and student perceptions of instructor humor orientation and socio-communicative style. Communication Education, 52(2), 122-134. https://doi.org/10.1080/03634520302469

Banas, J. A., Dunbar, N., Rodriguez, D., \& Liu, S. J. (2011). A review of humor in educational settings: Four decades of research. Communication Education, 60, 115-144. https://doi.org/10.1080/03634523.2010.496867

Berk, R. A. (2002). Humor as an instructional defibrillator: Evidence-based techniques in teaching and assessment. Sterling, VA: Stylus.

Bryant, J., Commiskey, P. W., Crane, J. S., \& Zillmann, D. (1980). Relationship between college teachers' use of humor in the classroom and students' evaluations of their teachers. Journal of Educational Psychology, 72, 511-519. https://doi.org/10.1037//0022-0663.72.4.511

Crawford, M. (2003). Gender and humor in social context. Journal of Pragmatics, 35, 1413-1430. https://doi.org/10.1016/s0378-2166(02)00183-2

Dieter, R. (2000). The use of humor as a teaching tool in the college classroom. NACTA Journal, 44, 20-28.

Frymier, A. B., Wanzer, M. B., \& Wojtaszczyk, A. M. (2008). Assessing students' perceptions of inappropriate and appropriate teacher humor. Communication Education, 57(2), 266-288.

Journal of the Scholarship of Teaching and Learning, Vol. 19, No. 5, December 2019.

josotl.indiana.edu 
https://doi.org/10.1080/03634520701687183

Garner, R. L. (2006). Humor in pedagogy: How ha-ha can lead to aha! College Teaching, 54(1), $177-$ 180. https://doi.org/10.3200/ctch.54.1.177-180

Goldberg, L. R., Johnson, J. A., Eber, H. W., Hogan, R., Ashton, M. C., Cloninger, C. R., \& Gough, H. G. (2006). The International Personality Item Pool and the future of public-domain personality measures. Journal of Research in Personality, 40, 84-96. https://doi.org/10.1016/j.jrp.2005.08.007

Goodboy, K. A., Booth-Butterfield, M., Bolkan, San, \& Griffin, D. J. (2015). The role of instructor humor and students' educational orientations in student learning, extra effort, participation, and out-of-class communication. Communication Quarterly, 63(1), 44-61. https://doi.org/10.1080/01463373.2014.965840

Gorham, J., \& Christophel, D. M. (1990). The relationship of teachers' use of humor in the classroom to immediacy and student learning. Communication Education, 39, 46-62. https://doi.org/10.1080/03634529009378786

Gough, H. G., \& Bradley, P. (1996). CPI Manual, $3^{\text {rd }}$ Edition. Palo Alto, CA: Consulting Psychologists Press.

Hackathorn, J., Garczynski, A. M., Blankmeyer, K., Tennial, R. D., \& Solomon, E. (2011). All kidding aside: Humor increases learning at knowledge and comprehension levels. Journal of the Scholarship of Teaching and Learning, 11(4), 116-123.

International Personality Item Pool: A Scientific Collaboratory for the Development of Advanced Measures of Personality Traits and Other Individual Differences (http://ipip.ori.org/). Internet Web Site.

Lampert, M., \& Ervin-Tripp, S. (1998). Exploring paradigms: The study of gender and sense of humor near the end of the $20^{\text {th }}$ century. In Willibald Ruch (Ed.), The sense of humor, pp. 231270. New York: Mouton de Gruyter.

Martin, R. (2007). The psychology of humor: An integrative approach. London: Elsevier Academic Press.

Martin, R., \& Kuiper, N. A. (1999). Daily occurrence of laughter: Relationships with age, gender, and Type A personality. Humor: The International Journal of Humor Research, 12(4), 355-384. https://doi.org/10.1515/humr.1999.12.4.355

Martin, D. M., Preiss, R. W., Gayle, B. M., \& Allen, M. (2006). A meta-analytic assessment of the effect of humorous lectures on learning. In B. M. Gayle, R. W. Preiss, N. Burrell, \& M. Allen (Eds.), Classroom communication and instructional processes: Advances through meta-analysis. (pp. 295313). Mahwah, NJ: Lawrence Erlbaum Associates, Inc., Publishers.

Martin, R. A., Puhlik-Doris, P., Larsen, G., Gray, J., \& Weir, K. (2003). Individual differences in the uses of humor and their relation to psychology well-being: Development of the Humor Styles Questionnaire. Journal of Research in Personality, 37, 48-75. https://doi.org/10.1016/s0092-6566(02)00534-2

Oppliger, P. A. (2003). Humor and learning. In J. Bryant, D. Roskos-Ewoldsen, \& J. Cantor (Eds.), Communication and emotion: Essays in honor of Dolf Zillmann (pp. 255-273). New York: Routledge.

Powers, T. (2008). Engaging students with humor. In B. Perlman, L. I. McCann, \& S. H. McFadden (Eds.), Lessons Learned, Volume 3: Practical advice for the teaching of psychology (pp. 53-62). Washington, DC: Association for Psychological Science.

Segrist, D. J., \& Hupp, Stephen, D. A. (2015). This class is a joke: Humor as a pedagogical tool in the teaching of psychology. Retrieved from http://teachpsych.org/Resources/Documents/otrp/resources/segrist15.pdf

Stuart, W. D., \& Rosenfeld, L. B. (1994). Student perceptions of teacher humor and classroom climate. Communication Research Reports, 11(1), 87-97. https://doi.org/10.1080/08824099409359944

Journal of the Scholarship of Teaching and Learning, Vol. 19, No. 5, December 2019. josotl.indiana.edu 
Torok, S. E., McMorris, R. F., \& Lin, W. C. (2004). Is humor an appreciated teaching tool? Perceptions of professors' teaching styles and use of humor. College Teaching, 52, 14-20. https://doi.org/10.3200/ctch.52.1.14-20

Van Giffen, K. (1990). Influence of professor gender and perceived use of humor on course evaluations. Humor, 3(1), 65-73. https://doi.org/10.1515/humr.1990.3.1.65

Wanzer, M. B., \& Frymier, A. B. (1999). The relationship between student perceptions of instructor humor and students' reports of learning. Communication Education, 48, 48-62. https://doi.org/10.1080/03634529909379152

Wanzer, M. B., Frymier, A. B., \& Irwin, J. (2010). An explanation of the relationship between instructor humor and student learning: Instructional humor processing theory. Communication Education, 59(1), 1-18. https://doi.org/10.1080/03634520903367238

Wanzer, M. B., Frymier, A. B., Wojtaszczyk, A. M., \& Smith, T. (2006). Appropriate and inappropriate uses of humor by teachers. Communication Education, 55, 178-196. https://doi.org/10.1080/03634520600566132

Wilson, J. H., Ryan, R. G., \& Pugh, J. L. (2010). Professor-student rapport scale predicts student outcomes. Teaching of Psychology, 37, 246-251. https://doi.org/10.1080/00986283.2010.510976

Wilson, J. H., \& Taylor, K. W. (2001). Professor immediacy as behaviors associated with liking students. Teaching of Psychology, 28(2), 136-138.

Yip, J. A., \& Martin, R. A. (2006). Sense of humor, emotional intelligence, and social competence. Journal of Research in Personality, 40, 1202-1208. https://doi.org/10.1016/j.jrp.2005.08.005 